\title{
PELA CONSTITUIÇÃO DE UMA REDE INTERNACIONAL EM TEORIA PSICANALÍTICA
}

$\mathrm{N}$

este número de Ágora, como no número especial editado em 2014, deu-se lugar à publicação de quatro textos apresentados nos colóquios internacionais "Subjetividades e montagens corporais no mundo contemporâneo" e "Dependência e drogas na adolescência: entre subjetividade e cultura”, organizados pelo Programa de Pós-Graduação em Teoria Psicanalítica da Universidade Federal do Rio de Janeiro junto a universidades francesas - a Université Paris Diderot e a Université Paris Descartes. Tais textos correspondem aos quatro primeiros artigos desta publicação. Evidentemente, todos eles foram avaliados por nossos consultores científicos, como se faz em qualquer número de Ágora, em nome do rigor teórico desta publicação.

Como no referido número anterior, o de agora visa consolidar as relações de troca científica entre o Programa de Pós-Graduação em Teoria Psicanalítica e as citadas instituições francesas. Seguindo uma regra de reciprocidade social no plano da universidade, esta é a contrapartida brasileira àquilo que as publicações universitárias francesas fazem com a publicação de colóquios organizados com a participação de pesquisadores brasileiros.

Por meio desta edição, pretende-se manter vivas as relações de troca com as instituições universitárias francesas, em nome da internacionalização do Programa de Pós-Graduação em Teoria Psicanalítica.

Joel Birman 